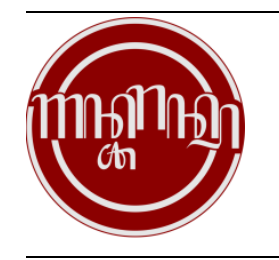

GHÂNCARAN: JURNAL PENDIDIKAN BAHASA DAN SASTRA INDONESIA

http://ejournal.iainmadura.ac.id/index.php/ghancaran

E-ISSN : 2715-9132; P-ISSN: 2714-8955

DOI 10.19105/ghancaran.vi.5619

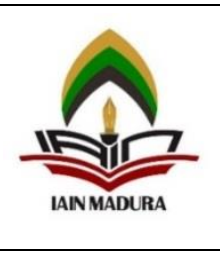

\title{
Strategi Multitalenta untuk Mengaktifkan Siswa dalam Pembelajaran Menulis Naskah Drama
}

\author{
Masyithah Maghfirah Rizam*, Kristanti Ayuanita**, Hesty Kusumawati** \\ *Tadris Bahasa Indonesia, IAIN Madura \\ **Tadris Bahasa Inggris, IAIN Madura \\ ***Tadris Bahasa Indonesia, IAIN Madura \\ Alamat surel: cthacix@gmail.com; kristanti@gmail.com; \\ hestykusumawati4@gmail.com
}

\begin{tabular}{ll}
\hline \hline & Abstract: \\
\hline Keywords: & Language skills that are important and used in everyday life, \\
Strategy; & one of which is writing skills. This writing skill is a form of \\
Muttitalented; & active productive skill because the writer actively produces or \\
Writing; & expresses his ideas. This research is a descriptive qualitative \\
Drama. & research that aims to describe a multitalented strategy to \\
& activate students in learning to write drama scripts. Innovative \\
& strategies are needed in learning to write drama scripts so \\
& that students are encouraged to be active, critical, and \\
& creative students. Multitalented Strategy is a strategy in which \\
& each student mobilizes all his talents in writing drama scripts.
\end{tabular}

\begin{tabular}{ll}
\hline \hline & Abstrak: \\
\hline Kata Kunci: & Keterampilan berbahasa yang penting dan digunakan dalam \\
Strategi; & kehidupan sehari-hari, salah satunya adalah keterampilan \\
Multitalenta; & menulis. Keterampilan menulis ini adalah bentuk \\
Menulis; & keterampilan aktif produktif karena penulis secara aktif \\
Drama. & memproduksi atau mengungkapkan ide gagasannya. \\
& Penelitian ini termasuk penelitian kualitatif deskriptif yang \\
& bertujuan mendeskripsikan strategi multitalenta untuk \\
& mengaktifkan siswa dalam pembelajaran menulis naskah \\
& drama. Strategi inovatif dibutuhkan dalam pembelajaran \\
& menulis naskah drama agar siswa didorong menjadi siswa \\
& aktif, kritis, dan kreatif. Strategi Multitalenta merupakan suatu \\
& strategi di mana setiap siswa mengerahkan seluruh talenta \\
& yang dimilikinya dalam menulis naskah drama.
\end{tabular}

\begin{tabular}{rrr}
\hline \hline Terkirim: 20-09-2021 & ; Revisi: 08-11-2021 & ; Diterima: 29-12-2021 \\
\hline \hline OGhâncaran: Jurnal Pendidikan Bahasa dan Sastra Indonesia \\
Tadris Bahasa Indonesia \\
Institut Agama Islam Negeri Madura, Indonesia \\
\hline \hline
\end{tabular}

\section{PENDAHULUAN}

Salah satu definisi "bahasa" adalah "sistem simbol yang memungkinkan orang untuk berkomunikasi atau berinteraksi. Simbol-simbol ini dapat mencakup bentuk vokal dan tertulis, gerak tubuh, dan bahasa tubuh." Cara lain untuk menggambarkan bahasa 
adalah dalam empat keterampilan dasar bahasa yaitu mendengarkan, berbicara, membaca, dan menulis. Mendengarkan dapat dipahami sebagai kegiatan ketika seseorang belajar bahasa baru, mereka pertama kali mendengarnya diucapkan. Lalu Berbicara, ketika akhirnya, mereka mencoba mengulangi apa yang mereka dengar. Dilanjutkan membaca ketika mereka melihat bahasa lisan digambarkan secara simbolis di media cetak dan menulis ketika pada akhirnya, mereka mereproduksi simbol-simbol tersebut di atas kertas.

Sebagai keterampilan bahasa aktif produktif, seorang penulis mampu mengungkapkan gagasan, ide, dan pikiran melalui tulisan, bukan hanya kepada beberapa orang seperti halnya berbicara, menulis jangkauannya relatif lebih luas. Seperti keterampilan berbahasa pada umumnya, seorang penulis akan menjadi mahir menulis dengan latihan yang dilakukan terus-menerus. Hal ini pun berlaku dalam menulis sastra.

Drama berasal dari kata Yunani 'drao' yang berarti tindakan atau melakukan. Drama berusaha memberikan seorang penulis tautan ke audiensnya di mana karyakarya mereka dibaca, dilakukan, dan ditafsirkan. Drama tidak hanya mengacu pada kata-kata tertulis, tetapi juga genre interpretatif, seperti pantomim, tarian dramatis di mana penari memiliki narasi untuk diikuti, tetapi juga nyanyian seperti Opera, Balet, dan Teater Musikal. Dalam sastra, drama didefinisikan sebagai karya sastra yang tujuan utamanya adalah untuk ditampilkan di depan penonton.

Drama adalah jenis sastra yang ditulis untuk tujuan ditampilkan di depan penonton. Jenis tulisan ini ditulis dalam bentuk naskah, dan cerita diceritakan melalui garis karakter yang diperankan oleh aktor. Seringkali dalam Drama seorang penulis dapat mengeksplorasi struktur plot, eksposisi, aksi naik, konflik, klimaks, dan penyelesaian. Penonton dapat mengalami dan mempelajari protagonis dan antagonis, tema dan moral yang dikaitkan. Penonton dapat melihat Drama yang sedang dipertunjukkan dan mereka dapat menafsirkan alur cerita dari sudut pandang mereka sendiri dan menarik kesimpulan dari apa yang mereka lihat, dengar, dan rasakan sebagai hasil dari pertunjukan itu.

Drama adalah tindakan dalam bentuk tertulis, dibuat untuk dilakukan dengan menggunakan dialog dan tindakan fisik untuk ditafsirkan oleh penonton.Drama dibangun melalui karya atau naskah yang diciptakan. Drama adalah interpretasi tertulis, skenario atau cerita yang biasanya melibatkan dialog, tindakan fisik dalam sebuah cerita. 
Drama dapat didefinisikan sebagai karya dramatis yang ditampilkan aktor di atas panggung. Sebuah cerita didramatisasi, yang berarti karakter dan peristiwa dalam cerita dihidupkan melalui pertunjukan panggung oleh aktor yang memainkan peran karakter dalam cerita dan bertindak melalui peristiwanya. Dalam memerankan peran, aktor menggambarkan emosi dan kepribadian karakter.

Tema adalah bagian yang merujuk pada kehidupan yang akan diangkat di dalam drama. Tema dapat dikatakan sebagai pondasi penulis dalam menulis naskah drama. Cerita merupakan dinding dari pondasi tersebut. Cerita tidak selalu memiliki alur maju lurus, namun dapat maju mundur, bisa jadi tidak beraturan atau kacau, sehingga nyaris bukan cerita tetapi hanya suasana-suasana. Cerita yang bertutur menjadikan naskah drama sebuah gambaran atau representasi kehidupan. Cerita yang tidak bertutur berupa pemikiran, sikap, dan rumusan mengandung nilai untuk dipakai dalam menghadapi barunya fenomena dalam kehidupan.

Terdapat kebutuhan akan tokoh, alur, konflik, dan lain-lain dalam membangun cerita. Penulis harus memikirkan jalan keluar dari masalah teknis tersebut.Diperlukan nilai-nilai yang menggugah, berani, yang merupakan hal yang baru. Dalam pesan moral, penulis menyampaikan langsung maupun tidak langsung pesannya. Watak, ideologi, pandangan hidup, dan filosofi penulis naskah bisa ditafsirkan melalui isi pesan moral Peserta didik atau pembaca dapat merasakan manfaat dari pesan moral tersebut terutama dalam pembelajaran di sekolah.

Menurut Depdiknas (2002:3-4) seperti dikutip oleh Aso (2008: 52), salah satu tujuan pembelajaran Bahasa dan Sastra Indonesia adalah siswa memiliki disiplin dalam berpikir dan berbahasa. Kaitannya dengan pembelajaran menulis adalah kegiatan tersebut sangat penting dilakukan untuk merealisasikan indikator pencapaian hasil belajar. Indikator pencapaian hasil belajar merupakan uraian kompetensi yang harus dikuasai oleh siswa dalam berkomunikasi secara spesifik yang dapat dijadikan ukuran untuk menuai ketercapaian hasil belajar.

Pembelajaran menulis sastra khususnya naskah drama perlu mendapatkan perhatian serius. Pada dasarnya ada tiga genre utama sastra - puisi, prosa dan drama dan masing-masing dapat diklasifikasikan lagi, menghasilkan banyak subgenre untuk masing-masing. Akan tetapi, sangat disayangkan jika kebanyakan guru masih menganakemaskan prosa dan puisi. Pengajaran prosa dan puisi cenderung lebih mendapat prioritas utama daripada pengajaran drama dan sikap seperti itu sudah tidak asing lagi dalam dunia pendidikan kita. Oleh sebab itu, dapat disebutkan bahwa 
pembelajaran drama baik itu menulis naskah drama maupun pementasan memiliki nasib tragis.

Pembelajaran menuntut suatu strategi pembelajaran yang dapat mendorong siswa menjadi siswa aktif, kritis, dan kreatif. Dalam pembelajaran menulis naskah drama, dibutuhkan suatu strategi yang dapat menyukseskan tujuan belajar dan pembelajaran. Penelitian yang berjudul "Strategi Multitalenta untuk Mengaktifkan Siswa dalam Pembelajaran Menulis Naskah Drama" ini diharapkan dapat menjadi strategi inovatif yang dapat memenuhi tuntutan pembelajaran tersebut.

\section{METODE}

Penelitian ini termasuk penelitian kualitatif deskriptif karena bertujuan untuk mendeskripsikan strategi multitalenta untuk mengaktifkan siswa dalam pembelajaran menulis naskah drama. Strategi inovatif dibutuhkan dalam pembelajaran menulis naskah drama agar siswa didorong menjadi siswa aktif, kritis, dan kreatif. Strategi Multitalenta merupakan suatu strategi yang diharapkan dapat mewujudkan hal tersebut. Strategi Multitalenta adalah sebuah strategi inovatif yang dapat memandu siswa dalam menulis naskah drama satu babak berdasarkan peristiwa-peristiwa menarik dalam suatu cerpen, menambahkan tokoh baru dalam cerpen tanpa mengubah isi cerpen, dan mengembangkan dialog tokoh-tokoh dalam naskah drama yang ditulis. Penambahan tokoh baru bertujuan agar naskah drama yang ditulis lebih berterima untuk diperankan oleh seluruh anggota kelompok siswa dalam pementasan sehingga siswa dituntut untuk kritis dan kreatif dalam menciptakan tokoh baru tersebut.

Strategi Multitalenta merupakan suatu strategi di mana setiap siswa mengerahkan seluruh talenta yang dimilikinya dalam menulis naskah drama. Multitalenta didasari pandangan bahwa setiap manusia memiliki berbagai kepandaian yang telah dianugerahkan Allah. Kepandaian tersebut sudah dibawa sejak lahir ke dunia. Strategi Multitalenta mendorong siswa untuk mengerahkan talenta-talentanya dalam penulisan naskah drama berupa kepandaian dalam menyusun struktur fisik (alur, penokohan/perwatakan, dialog, latar, dan teks samping/petunjuk teknis) dan batin (tema dan amanat) drama sehingga menjadi naskah drama yang baik yang dilakukan bersama dengan siswa lain dalam satu kelompok. Meskipun penulisan naskah drama berlangsung dalam kelompok, tujuan pembelajaran adalah tetap untuk mengaktifkan setiap siswa menulis naskah drama.

Strategi Multitalenta diadaptasi dari pembelajaran kooperatif. Pembelajaran kooperatif didasarkan pada kerja kelompok. Elemen inti dari pembelajaran kooperatif 
adalah untuk menunjukkan efek positif dari saling ketergantungan dengan tetap menggarisbawahi pentingnya tanggung jawab pribadi. Hal ini terjadi secara alami dalam pembelajaran kooperatif karena siswa bekerja satu sama lain, tetapi mereka semua memiliki tugas yang berbeda untuk diselesaikan atau konsep untuk dijelaskan. Keuntungannya tentu siswa menjadi belajar bersosialisasi saat mereka bekerja dalam pembelajaran kooperatif.

\section{HASIL DAN PEMBAHASAN}

Pembelajaran kooperatif adalah metode pembelajaran di mana siswa bekerja dalam kelompok-kelompok kecil untuk mencapai tujuan pembelajaran bersama di bawah bimbingan guru. Strategi pembelajaran kooperatif memberikan siswa kemungkinan untuk belajar dengan menerapkan pengetahuan dalam lingkungan yang lebih mirip dengan yang akan mereka hadapi dalam kehidupan kerja masa di depan mereka.

Dalam pembelajaran kooperatif, guru mendapat kesempatan untuk bekerja pada kompetensi inti, mengintegrasikannya dalam kurikulum sekolah. Sehingga guru dapat membantu siswa agar mereka memiliki soft skill yang berharga bagi keberhasilan siswa dalam kehidupan dan pekerjaannya kelak. Strategi pembelajaran kooperatif adalah struktur bebas konten yang dapat digunakan kembali dalam konteks sekolah yang berbeda.Strategi tersebut dapat digunakan baik berpasangan maupun kelompok dan dirancang untuk memenuhi prinsip saling ketergantungan positif, akuntabilitas individu, partisipasi setara, dan interaksi simultan.

Secara umum kita berbicara tentang saling ketergantungan positif ketika keuntungan untuk satu adalah manfaat bagi yang lain. Pasangan dan anggota kelompok mendapatkan pengalaman sebagai sebuah tim dan berada di sisi yang samasama bekerja menuju tujuan yang sama. Untuk memastikan saling ketergantungan yang positif saat bekerja dengan pembelajaran kooperatif, dua syarat harus dipenuhi: siswa harus merasa berada di sisi yang sama dan tugas harus membutuhkan kerja sama.

Di kelas kooperatif, siswa bekerja sama sebagai tim untuk membuat dan belajar, tetapi pada akhirnya setiap siswa bertanggung jawab atas kinerjanya sendiri. Justru untuk memenuhi saling ketergantungan positif dan akuntabilitas individu bahwa dalam setiap strategi pembelajaran kooperatif siswa diberikan waktu untuk berpikir/bekerja sendiri dan untuk berinteraksi dengan teman sebaya. Dengan cara ini otonomi dan kerjasama siswa ditingkatkan. 
Manfaat yang diperoleh siswa dari bekerja sama secara kooperatif yakni siswa memiliki kesempatan untuk berbagi pengetahuan mereka dan mengembangkan pemahaman yang lebih jelas tentang apa yang mereka pelajari. Ketika siswa memiliki kesempatan untuk bekerja dengan orang lain, mereka belajar untuk mendengarkan orang lain, mempertimbangkan perspektif mereka tentang suatu topik, menantang ide orang lain, dan berkomunikasi dengan cara yang dapat diterima oleh kelompok. Ini adalah perilaku yang membantu membangun hubungan kerja yang positif saat siswa belajar memahami bahwa ada cara berperilaku dalam kelompok yang perlu mereka terima jika mereka ingin terus bekerja secara konstruktif dengan rekan-rekan mereka. Cara kerja ini juga berkontribusi pada tingkat harga diri yang lebih tinggi bagi siswa.

Manfaat lain pembelajaran kooperatif termasuk kelompok akan sering mengingatkan siswa yang menjadi "pengganggu" tentang kebutuhan untuk bekerja sama dalam menyelesaikan tugas. Pembelajaran kooperatif juga mendorong penerimaan yang lebih besar dari orang lain, dan siswa akan sering menggunakan bahasa yang lebih inklusif dari orang lain seperti 'kita'. Mereka juga belajar untuk memberikan penjelasan yang lebih rinci kepada rekan-rekan mereka ketika mereka diminta untuk menjelaskan informasi atau untuk membantu menyelesaikan suatu masalah.

Pembelajaran kooperatif melibatkan penekanan pada keragaman daripada keseragaman pengajaran, yang berarti bahwa guru dapat memastikan bahwa siswa diberi tugas yang berpotensi mereka selesaikan. Ini juga memungkinkan fleksibilitas yang lebih besar untuk menyesuaikan tujuan pembelajaran, karena guru dapat menyesuaikan tugas untuk memenuhi kebutuhan siswa tertentu dalam kelompok. Ketika siswa melatih materi secara lisan, menjelaskannya kepada orang lain, menemukan solusi, berdebat dan mendiskusikan masalah prosedural dalam kelompok kecil, mereka mengkonsolidasikan pembelajaran mereka sendiri serta berkontribusi pada pembelajaran orang lain.

Pembelajaran kooperatif memberikan kesempatan untuk meningkatkan keterampilan berpikir tingkat tinggi dan mengembangkan keterampilan sosial dan komunikasi, dan memotivasi siswa untuk mempelajari informasi. Bekerja dalam kelompok kooperatif sangat menguntungkan siswa berprestasi rendah, karena memberikan kesempatan untuk mengulang pembelajaran dan memperkuat dengan cara yang berbeda yang membantu mengkonsolidasikan pembelajaran. 


\section{Acuan dalam Menulis Naskah Drama}

Naskah drama mengikuti struktur plot naratif yang jelas dan mengandung elemen sastra-seperti karakter, latar, dan gaya-yang membantu penonton menganalisis dan menafsirkan cerita.

Eksposisi: Siapkan dan perkenalkan semuanya melalui eksposisi, yang memaparkan informasi latar belakang cerita Anda. Garis besar karakter utama, pengaturan, dan periode waktu. Salah satu cara untuk melewati eksposisi dalam skenario Anda adalah dengan memiliki setidaknya satu karakter yang menimbulkan rasa penasaran pada penonton: Karakter tersebut dapat memunculkan pertanyaanpertanyaan penonton, sehingga memperjelas berbagai plot.

Rising action: Perkenalkan konflik utama cerita dengan rising action, yaitu rangkaian peristiwa dalam cerita yang menimbulkan ketegangan dan membangun klimaks. Misalnya, di Hamlet karya Shakespeare, aksi yang meningkat terjadi ketika hantu ayah Hamlet memberi tahu Hamlet bahwa Claudius membunuhnya. Niat Hamlet menjadi jelas - untuk membalas kematian ayahnya — dan ceritanya dimulai.

Klimaks: Bangun cerita ke puncak ketegangan, dan capai titik balik untuk karakter utama. Biasanya, klimaks dari sebuah cerita terjadi ketika karakter utama harus menghadapi kenyataan dan membuat pilihan penting.

Penyelesaian: Tunjukkan hasil dari apa yang terjadi ketika karakter utama membuat pilihan penting. Penyelesaian adalah ketika ujung-ujung yang longgar diikat, ketegangan menghilang, dan konflik memberi jalan kepada penyelesaian.

Kesimpulan: Tutup cerita. Tunjukkan bagaimana ketegangan memengaruhi karakter dan dunia di sekitar mereka.

\section{Langkah-langkah Strategi Multitalenta}

Menurut Ghazali (2010:316), untuk mengembangkan kompetensi menulis dengan menggunakan perspektif yang bertumpu pada proses (process-centered approach), ada beberapa kegiatan pembelajaran yang bisa digunakan pada berbagai fase yang berbeda dari kegiatan menulis. Fase atau tahapan dalam strategi Multitalenta untuk mengaktifkan siswa dalam pembelajaran menulis naskah drama itu terdiri dari tiga tahapan. Tentunya dalam hal ini siswa dibuat dalam kelompok-kelompok kecil, bisa terdiri dari 3-5 siswa. Selanjutnya dalam kelompok-kelompok kecil tersebut melaksanakan tiga tahapan yakni tahapan persiapan menulis, penulisan, dan revisi yang diuraikan sebagai berikut. 


\section{Tahapan Persiapan Menulis}

Pada tahapan persiapan menulis, siswa dalam kelompok kecil menyimak arahan dari guru tentang kegiatan pencarian ide yang harus dilakukan dalam mengangkat suatu cerita pendek menjadi sebuah naskah drama. Siswa saling bertukar informasi tentang peristiwa menarik dalam cerpen yang akan ditulis menjadi naskah drama. Peserta didik membandingkan sikap dan pandangan mereka masing-masing tentang masalah atau konflik dalam drama yang akan ditulis berdasarkan cerpen.

Siswa mendaftar tokoh baru yang akan diciptakan dan penokohannya. Menurut Santosa (2008: 90), penokohan memiliki peran penting. Bahkan Lajos Egri menjelaskan bahwa penokohan merupakan hal yang diprioritaskan dalam drama. Jika tidak ada penokohan maka tidak akan ada cerita, tidak akan ada alur. Perbedaan watak tokoh dapat memunculkan pergeseran dalam cerita, memunculkan kepentingan yang bertabrakan, hingga konflik yang sangfat dibutuhkan oleh cerita drama.

\section{Tahapan Penulisan}

Pada tahapan penulisan, siswa berbagi tugas dalam kelompok kecilnya untuk mengorganisasikan ide-ide ke dalam kerangka drama. Kerangka drama didiskusikan baik dengan kelompok siswa lain dan guru. Siswa secara berkelompok menulis drama sebabak. Pada tahapan menulis, siswa harus memperhatikan kesesuaian dialog dengan tahapan cerita pada kerangka drama. Siswa harus memperhatikan kesesuaian dialog dengan tokoh dan perwatakannya.

\section{Tahapan Revisi}

Pada tahapan revisi, antar kelompok diminta untuk saling membaca, mengritik, dan memperbaiki tulisan mereka sendiri. Guru memberikan sarana bantuan untuk revisi misalnya memberikan pertanyaan yang berguna untuk mempersiapkan siswa dalam merevisi tulisan.

\section{Penerapan Strategi Multitalenta}

Berikut ini, penerapan strategi multitalenta dalam menulis naskah drama. Terdapat tujuh langkah menulis naskah drama berdasarkan starategi multitalenta.

\section{Strategi Multitalenta Dalam Menentukan Tema}

Menentukan tema dilakukan dalam kelompok kecil agar siswa dapat terasah mengajukan ide-idenya dalam kelompok kecil tersebut. Sebagai gagasan dasar cerita atau pesan yang disampaikan pengarang, tema menuntun laku cerita hingga akhir. Misal tema yang digunakan adalah "kebaikan hati akan menuntun seseorang melakukan hal-hal yang benar", maka kisah dalam drama akan memunculkan aksi 
tokoh baik yang melakukan banyak hal benar sehingga penonton dapat memahami tema tersebut.

\section{Strategi Multitalenta Dalam Menentukan Persoalan}

Dalam menentukan persoalan juga dilakukan siswa dalam kelompok kecil, dengan saling berbagi ide dalam menentukan persoalan. Pusat pengisahan dalam drama adalah konflik atau permasalahan. Tidak ada cerita drama tanpa konflik. Oleh karena itu pangkal persoalan atau titik awal konflik perlu dibuat dan disesuaikan dengan tema yang dikehendaki. Misalnya dengan tema "kebaikan akan mengalahkan kejahatan", pangkal persoalan yang dibicarakan adalah sikap licik seseorang yang selalu memfitnah orang lain demi kepentingannya sendiri. Persoalan ini kemudian dikembangkan dalam cerita yang hendak dituliskan.

\section{Strategi Multitalenta dalam Membuat Ringkasan Cerita (Sinopsis)}

Siswa bekerja sama membuat ringkasan cerita atau sinopsis dalam kelompok kecil. Dengan mengggunakan strategi Multitalenta, peserta didik diharapkan menuliskan ringkasan cerita secara hingga akhir. Ringkasan cerita atau sinopsis ini akan berguna untuk memandu peserta didik menulis naskah. Melalui ringkasan cerita, maka akan meminimalkan melebarnya atau tidak terarahnya persoalan sehingga alur yang diinginkan menjadi jelas. Ringkasan cerita akan membantu cerita menjadi jelas dan terarah.

\section{Strategi Multitalenta dalam Menyusun Kerangka Cerita}

Siswa bekerja sama menyusun kerangka cerita dalam kelompok kecil. Kerangka cerita dapat berfungsi sebagai bingkai bagi sebuah drama. Kerangka cerita drama dapat mengarahkan cerita dari pemaparan, konflik, klimaks, sampai penyelesaian. Kegunaan menyusun kerangka cerita dalam drama adalah peserta didik dalam hal ini penulis drama memiliki batasan yang jelas dalam cerita dramanya. Menyusun kerangka cerita drama bisa dengan menyusun bagian pembuka, inti, dan penutup. Pada bagian pembuka dapat dipaparkan sekilas tokoh dan penokohan dalam drama. Bagian inti dapat berisi rincian konflik yang dialami tokoh, hingga konflik tersebut memuncak. Pada bagian penutup, konflik sudah dapat dipecahkan,

\section{Strategi Multitalenta dalam Mewujudkan Tokoh Protagonis}

Selanjutnya siswa dalam kelompok kecilnya dapat mewujudkan tokoh protagonis bersama. Dapat dikatakan, tokoh protagonis adalah tokoh yang mendukung tema, sehingga tokoh protagonist ini memiliki lakuan dalam keseluruhan cerita. Tokoh protagonis harus ditentukan secara mendetail sehingga tokoh lainnya mudah diidentifikasi. Contoh dalam "kebaikan hati akan menuntun seseorang melakukan hal- 
hal yang benar", maka protagonis dapat diwujudkan sebagai orang yang jujur, suka menolong, dan sifat-sifat terpuji lainnya. Sifat protagonis yang detail akan memperjelas sifat antagonis.. Setelah terbentuknya tokoh protagonis dan antagonis akan menyebabkan kemudahan dalam membentuk tokoh lain yang berada di pihak protagonis maupun antagonis.

\section{Strategi Multitalenta dalam Menyelesaikan Cerita Drama}

Dalam hal ini siswa bekerja sama menyelesaikan cerita drama dalam kelompok kecilnya. Menyelesaikan konflik dalam drama tentu bukan hal yang mudah. Beberapa drama diakhiri dengan baik namun yang lain tidak demikian, bahkan memiliki akhir cerita yang membingungkan bagi penontonnya. Penonton tentu menantikan akhir cerita yang mengesankan. Maka, menentukan akhir dari cerita drama harus memerhatikan kelogisan dan aspek kemenarikan bagi penonton.

\section{Strategi Multitalenta dalam Menulis Keseluruhan Naskah Drama}

Siswa dalam kelompok kecilnya berbagi tugas untuk menulis keseluruhan naskah drama. Tahap-tahap strategi multitalenta berikutnya adalah menulis. Setelah semua dipersiapkan, penulis naskah drama dapat menuangkan ide gagasannnya dalam bentuk tulisan. Penulis perlu memanfaatkan waktu sebaik-baiknya agar langkahlangkah strategi multitalenta dapat mempermudahnya dalam menulis naskah drama. Dengan mematuhi semua langkah-langkah diharapkan langkah terakhir dapat dilaksanakan dengan baik.

\section{SIMPULAN}

Kemahiran dalam menulis drama dapat dicapai melalui proses belajar dan latihan menulis drama secara terus menerus. Dengan menggunakan strategi Multitalenta, siswa dapat melakukan latihan menulis drama dengan fokus dan berkesinambungan. Fase atau tahapan dalam strategi Multitalenta untuk mengaktifkan siswa dalam pembelajaran menulis naskah drama terdiri dari tiga tahapan. Tiga tahapan tersebut yakni tahapan persiapan menulis, penulisan, dan revisi. Langkah menulis naskah drama dalam strategi Multitalenta yaitu menentukan tema, persoalan, membuat sinopsis (ringkasan cerita), menentukan kerangka cerita, protagonis, cara penyelesaian, dan menulis naskah drama.

\section{DAFTAR PUSTAKA}

Aso, Andi. (2008). Pembelajaran Menulis Drama Sebabak dengan Strategi Modelling untuk Meningkatkan Hasil Belajar Siswa Kelas VIII D SMP Negeri 2 Palu. Derap Pendidikan LPMP Sulawesi Tengah, 2(3): 50-60. 
Ghazali, A. Syukur. (2010). Pembelajaran Keterampilan Berbahasa dengan Pendekatan Komunikatif-Interaktif. Bandung: PT Refika Aditama.

Nurhadi. (2005). Menulis Naskah Drama, (Online), (http://staff.uny.ac.id/sites/default/files/tmp/PPM-Menulis\%20Naskah\%20DramaPLPG, diakses 17 April 2012).

Nurhadi., \& Senduk, Agus Gerrad. (2009). Pembelajaran Kontekstual. Surabaya: PT. JePe Press Media Utama.

Santosa, Eka. (2008). Seni Teater (Jilid 1). Jakarta: Direktorat Pembinaan Sekolah Menengah Kejuruan.

Sumaryadi. (2008). Seni Drama dan Pendidikan Karakter, (Online), (hhtp://staff.uny.ac.id/sites/default/files/drama-karakter, diakses 17 April 2012).

Roem, Akmal M. (2009). Kiat Menulis Naskah Drama (Putu Wijaya), (Online), (http://aamovi.wordpress.com/2009/03/31/kiat-menulis-naskah-drama-putu-wijaya, diakses 17 April 2012). 